\title{
Three-port versus standard four-port laparoscopic cholecystectomy: A clinical trial
}

\author{
D Tamer Akay, ${ }^{1}$ (1) Serhat Örün, ${ }^{2}$ 이 Metin Leblebici $^{3}$ \\ 'Department of General Surgery, Bandırma State Hospital, Balıkesir, Turkey \\ 2Department of Emergency Medicine, Namık Kemal University Faculty of Medicine, Tekirdağ, Turkey \\ ${ }^{3}$ Department of General Surgery, İstanbul Medeniyet University Göztepe Training and Research Hospital, İstanbul, Turkey
}

\begin{abstract}
Introduction: After the first laparoscopic cholecystectomy was performed in 1987, the 4-port operation technique became the standard worldwide. This study is a comparison of the intraoperative complications observed using 3-port and 4-port methods, and an examination of the reliability of the 3-port method.

Materials and Methods: The files of 400 patients who underwent a laparoscopic cholecystectomy due to gallbladder disease between 2014 and 2019 were analyzed. The patients were divided into 2 groups according to the use of a 3-port or a 4-port method, and the intraoperative complications of the groups were compared.
\end{abstract}

Results: A total of 400 patient files were reviewed and the only significant difference between the 2 groups among the parameters of age, gender, and weight was the female-male ratio. Of the 3 -port cases, $13.5 \%$ were male, and $86.5 \%$ were female. Of the 4 -port cases, $23.5 \%$ were male and $76.5 \%$ were female $(p=0.010)$. A significant difference was not seen between the 2 groups with respect to the mean operation time $(p=0.548)$ or operation success $(p=0.253)$. The average hospitalization period was longer in the 3 -port group ( 1.98 days vs 1.18 days, respectively; $p<0.001)$. No significant difference was found in the number of intraoperative complications: gallbladder perforation $(p=0.215)$, liver laver hemorrhage $(p=0.481)$, entry of the gallstone into the abdomen $(p=0.760)$, and choledoch injury $(p=0.522)$.

Conclusion: The success rate of a laparoscopic cholecystectomy was similar in the 3-port and 4-port groups. The mean length of hospitalization was longer in the 3-port group compared with the 4-port group. Analysis suggested that the greater number of intraoperative complications in the 3-port group had an effect on the hospitalization period. There were no instances of further complications developing after the 3-port procedure.

Keywords: Laparoscopic cholecystectomy; operating ports; surgical technique; trocars.

\section{Introduction}

Laparoscopic cholecystectomy is a surgical method, which is preferred as a standard with regard to symptomatic gallstone disease and other benign gallbladder dis- eases. ${ }^{[1]}$ The first laparoscopic cholecystectomy has been performed by Phillip Mouret, in 1987; and is improved by Dubois and Perissat in $1990 .^{[2,3]}$ There has been changes 
with respect to port locations and port numbers in laparoscopic cholecystectomy, as the experiences of the surgeons is increased. ${ }^{[4-8]}$ The certain changes within the method enabled some special methods to be emerged, especially as French and American techniques. These two techniques are recognized generally, and the difference between these techniques is in terms of the difference between the uses of the fourth port. ${ }^{[9-13]}$ When we experience the use of the fourth port in laparoscopy, we see it has a little role in operation with American technique, and therefore many surgeons have published that performing operations with three-port without using the fourth port (lateral port) reduces the operation time as their experiences grow. ${ }^{[14,15]}$ However, it is seen that standard four-port method is uses in many publications in the literature. ${ }^{[16]}$ Some studies showed that the three-port method has reduced the pain of the patients and the costs. ${ }^{[17]}$ Many studies have shown that the number of the ports used and the decrease of the size had an influence on reducing the post-operative pain. ${ }^{[1718]}$ Exposure to intra-operative complications plays a very important role on the safety of the surgical method. Therefore, the files of the patients, who underwent three- port and four-port laparoscopic cholecystectomy are compared in respect of the intra-operative complications' results, in this study.

\section{Materials and Methods}

\section{Patients}

750 files of the patients, who underwent laparoscopic cholecystectomy due to gallbladder disease between 2014 and 2019 were investigated. The criteria for patients to be eligible for the study was having gallbladder polyps and gallstones. The criteria for being excluded for the study were the patients with acute pancreatitis, choledocholithiasis, gallbladder empyema, portal hypertension,malignancy; patients with hemorrhage disorder, acute cholecystitis, the patients who underwent upper gastrointestinal surgeries, the patients with a body mass index of over 40, and ASA Grade IV patients which general anesthesia is risky in respect of anesthesia.Pursuant to the exclusion criteria, 350 patient files removed, and 400 patient files divided into two groups as 3-port $(n=200)$ and 4-port $(\mathrm{n}=200)$. The parameters which was compared between the two groups in the study, were divided into three groups; the gender, age and weight of the patients remain in the first group; operation time (the period between incision and the closure of the wound), success rate (laparoscopic completion of the patients' operation without complications and no need for additional trocar) and hospitalization period remain in the second group; and intra-operative complications such as gallbladder perforation, infusion of gallstone from gallbladder into the abdomen, hemorrhage from the liver laver and choledoch injury remain in the third group.

\section{Techniques}

Lying positions of all patients were in supine, reversetrendelenburg and left-lateralized positions. American technique was used in operations performed with fourport. In this technique, a trocar in $11 \mathrm{~mm}$ has been placed under the umbilicus, a trocar in $10 \mathrm{~mm}$ has been placed under the xiphoid, and two trocars in $5 \mathrm{~mm}$ have been placed within sub-costal area. The general surgeon performing the operation and the assistant nurse (the nurse holding the camera) was on the left side of the patient, while the other nurse was on the right side of the patient.

In three-port technique, 1 piece $10 \mathrm{~mm}$ trocar was placed through umbilicus area as openly with Hasson's technique, then a $5 \mathrm{~mm}$ trocar was inserted from falciform ligament's lateral in epigastrium area with the aid of video laparoscopy. The other $5 \mathrm{~mm}$ trocar was inserted into the abdomen through the midclavicular line, $2-3 \mathrm{~cm}$ below the right costal line. The operations have been performed by the surgeon, using the two ports, while the assistant nurse was manipulating the camera.

The -Stryker brand - video laparoscopy device (Stryker, 1488 HD 3-Chip camera system, San Jose, CA, USA) was placed on the right corner of the patient's head during the operation. While dissecting the lower and rear parts of cystic ductus, the infundibulum was retracted by entering through the grasper midclavicular port. The Calot angle is revealed by retracting the infundibulum, and the cystic ductus and cystic artery is dissected. After the cystic ductus is dissected, it is clipped and separated, and the cystic artery is revealed. The cystic artery is clipped and separated, and the gallbladder is removed away from the gall laver via the grasper, and then cholecystectomy is completed via the hook, gallbladder is removed from the gall laver, and the operation is concluded by closing the port locations after the gallbladder is taken out of the abdomen and the Jackson Pratt drain (Cardinal Health, McGaw Park, IL, USA) is placed into the gall laver as a routine. 


\section{Statistical Analysis}

Independent-test was used to evaluate the significance of each parameter. For analysis of the visual analogue scores, which were not normally distributed, the MannWhitney U test was used. Chi-square was used to compare proportions.

\section{Results}

400 files of patients, who has underwent laparoscopic cholecystectomy due to gallbladder disease between 2014 and 2019, are investigated. When the demographic data is investigated, 27 cases were men (13.5\%) and 173 cases were women (86.5\%) among the cases operated with 3-port. 47 cases were men (23.5\%), and 153 were women (76.5\%) among the cases operated with 4-port. The average age of the cases, which were operated with 3-port, was 50.8 (range, 19-88 ages), the average age of the cases, which were operated with 4-port, was 51.4 (range, 22-79 ages). The average weight of the cases, which were operated with 3-port, was $72.7 \mathrm{~kg}$ (range, 55-102 kg), the average weight of the cases, which were operated with 4-port, was $74.7 \mathrm{~kg}$ (range, 52-106 kg) (Table 1).

When the general parameters, related with the surgery, are investigated, the average operation time of the cases, which were operated with 3-port, was $61.1 \mathrm{~min}$. (range, 40-118 min.), the average operation time of the cases, which were operated with 4-port, was $58.8 \mathrm{~min}$. (range, 38-126 min.). The average hospitalization period of the cases, which were operated with 3-port, was 1.98 days (range, 1-10 days), and the average hospitalization period of the cases, which were operated with 4-port, was 1.18 days (range, 1-6 days).

In 3 of the patients, who were operated with 3-port there has been a need for additional trocar, however upon the hemorrhage from the liver laver could not been controlled, then conventional cholecystectomy was applied. Besides, upon the gall fistula is developed in 2 cases, there has been a need for additional trocar, and upon the gall fistula is developed in 1 of them after the operation, then laparotomy decision was taken. The operation success rate of the cases, which were operated with 3-port, was $97.5 \%$ (195 patients). Upon the hemorrhage from the liver laver could not been controlled in 1 case, who was operated with 4-port, then conventional cholecystectomy was applied. Besides, upon gall peritonitis development in 1 case after the operation, laparotomy decision was taken. The operation success rate of the cases, which were operated with 4-port, was 99\% (198 patients) (Table 2).

When the two groups are investigated in respect of the intraoperative complications; it was determined that the gallbladder's perforation rate of the cases, which were operated with 3-port, was 5.5\% (11 patients), and the gallbladder's perforation rate of the cases, which were operated with 4-port, was 3\% (6 patients). Infusion rate of gall stones into the abdomen was 3\% (6 patients) in the cases operated with 3-port method, and the infusion rate of gall stones into the abdomen was $2.5 \%$ (5 patients) in the cases operated with 4-port method. The bleeding from the liver

Table 1. Demographic data

\begin{tabular}{lccc} 
& Group 1 (three trocars) $(\mathbf{n = 2 0 0 )}$ & Group 2 (four trocars) $(\mathbf{n = 2 0 0 )}$ & p-value \\
\hline Age (years) & $50.87 \pm 14.8$ & $51.49 \pm 13.3$ & $0.660^{*}$ \\
Gender ratio $(\mathrm{M} / \mathrm{F}), \mathrm{n}(\%)$ & $27(13.5) / 173(86.5)$ & $47(23.5) / 153(76.5)$ & $0.010^{* *}$ \\
Weight $(\mathrm{kg})$ & $72.70 \pm 9.43$ & $74.73 \pm 11.24$ & $0.051^{*}$ \\
\hline
\end{tabular}

"Independent test; " ${ }^{*}$ Chi-square test; ${ }^{\star \star *}$ Mann-Whitney U test. M: Male; F: Female.

Table 2. Patient outcomes

\begin{tabular}{|c|c|c|c|}
\hline & Group 1 (three trocars) $(n=200)$ & Group 2 (four trocars) $(n=200)$ & p-value \\
\hline Operating time (min) & $61.18 \pm 15.75$ & $58.82 \pm 15.37$ & $0.548^{* \star *}$ \\
\hline Postop stay (d) & $1.98 \pm 1.17$ & $1.18 \pm 0.61$ & $<0.001^{* * *}$ \\
\hline Success rate & $195(97.5)$ & $198(99.0)$ & $0.253^{\star *}$ \\
\hline
\end{tabular}


Table 3. Intra-operative complications in the two study groups

\begin{tabular}{lccc|}
\hline Intra-operative findings & $\begin{array}{c}\text { Group } \mathbf{1} \text { (three trocars) } \\
(\mathbf{n = 2 0 0 )}\end{array}$ & $\begin{array}{c}\text { Group 2 (four trocars) } \\
(\mathbf{n = 2 0 0 )}\end{array}$ & $\begin{array}{c}\text { Chi square } \\
\text { value }\end{array}$ \\
\hline GB perforation, $\mathrm{n}(\%)$ & $11(5.5)$ & $6(3.0)$ & $0.215^{\star *}$ \\
Stones spillage, $\mathrm{n}(\%)$ & $6(3.0)$ & $5(2.5)$ & $0.760^{\star *}$ \\
Bleeding from the liver laver, $\mathrm{n}(\%)$ & $11(5.5)$ & $8(4.0)$ & $0.481^{* *}$ \\
Coledoc injury, $\mathrm{n}(\%)$ & $6(3.0)$ & $4(2.0)$ & $0.522^{* *}$
\end{tabular}

"Independent test; " ${ }^{*}$ Chi-square test; ${ }^{\star \star *}$ Mann-Whitney U test.

laver of the cases, which were operated with 3-port, was $5.5 \%$ (11 patients), and the bleeding from the liver laver of the cases, which were operated with 4-port, was $4 \%$ (8 patients). The choledoch injury rate of the cases, which were operated with 3-port, was 3\% (6 patients), and the choledoch injury rate of the cases, which were operated with 4-port, was $2 \%$ (4 patients) (Table 3).

\section{Discussion}

When we were planning our study; the files of the patients, who were operated with three-port and four-port method, are reviewed retrospectively. We were able to review the outcomes by selecting the complications we have encountered in the files, in state of the pain or cost parameters as in other studies. We compared the intra-operative complications regarding the three-port method, as whether it is safe or not in this matter. When we reviewed the files, we saw that major vein injuries or hollow organ perforation have not been developed. When we reviewed the age, gender and weight parameters of our study, only a significant difference between the two groups is determined in respect to the men-women ratio (27(13.5)/173(86.5)47(23.5)/153(76.5), $\mathrm{p}=0.010)$. When the similar studies are reviewed, it is seen that any statistical difference has not been determined between the demographical data. ${ }^{[4,19-21]}$ The success rate of the laparoscopic cholecystectomy is determined in a similar rate in 3-port and 4-port groups. This result shares similarity with the studies carried out today. ${ }^{[4,5,18,22]}$ The average hospitalization period is determined as longer in 3-port group, when compared with 4-port group (1.98-1.18, $\mathrm{p}<0.001)$. When the reason of this situation is investigated, it is thought that out number of the patients in 3-port group (34 patients), which the intraoperative complications were developed, were more than those within the 4-port group (23 patients), had an effect on the hospitalization periods. In the similar studies, any significant difference has not been determined statisti- cally in respect of hospitalization periods. ${ }^{[4,6,17]}$ In Kumar et al.'s ${ }^{[22]}$ study, the hospitalization period was found to be shorter in 3-port group (1.19-1.44, p=0.39). In our study, any statistically significant difference is not determined in respect of average operation times. The average operation time for 4-port cholecystectomy is found to be between $34-59 \mathrm{~min}$. in the studies. ${ }^{[4-6,23]}$ In our study this time is average 38-126 min., and it is longer time than in the literature.When its reason is investigated, it is thought that it is due to the operation times of the complicated cases.In Kumar et al.' $\mathrm{s}^{[2]}$ study, the operation time was determined as to be shorter in three-port method (47.3 min vs. 60.8; $\mathrm{p}=0.04$ ). Placement of the fourth trocar, not allocating time for the retraction of fundus, and not allocating time for closure of the fourth trocar' locations are shown as the reasons.

In laparoscopic cholecystectomy operations, the gallbladder perforation appears as a common complication. As seen in many publications, the incidence of this complication varies between $16-33 \%$. In Harsha HS et al.'s ${ }^{[24]}$ study, in 2013, this complication's incidence in operations performed with three-port method was found to be less than the others, and also than the classic four-port method. ${ }^{[25]}$ In our study, 11 gallbladder perforation incidences were determined in three-port method, and 6 gallbladder perforation incidences were determined in four-port method $(\mathrm{p}>0.05)$.

The other complication is the infusion of gallstones into the abdomen. In our study, the infusion of the gallstones into the abdomen is determined in similar rates as \%3-2.5 in each method, and it shares similarity with the literature. ${ }^{[26]}$ Bleeding from the liver laver during laparoscopic cholecystectomy does not vary across the two groups statistically (\%5.5-4), and it is similar with the literature. ${ }^{[26,27]}$ In our study, hemorrhage from the liver laver occurred and additional trocar need emerged in 3 patients within 
three-port group, however they were explored when the hemorrhage could not been taken under control. 1 patient within four-port group was explored due to not being able to stop the hemorrhage from the liver laver laparoscopically. The liver laver was sutured, and hemorrhage was taken under control.

The choledoch injury is one the most important complications of laparoscopic cholecystectomy. Gall fistula was determined in 6 patients, who have underwent laparoscopic cholecystectomy with three-port method, and in 4 patients, who have underwent laparoscopic cholecystectomy with four-port method, and in 2 patients, who have been operated with three-port operation, upon the patient's clinic did not retrograde following the endoscopic retrograde cholangiopancreatography (ERCP) operation, it was decided to undergo re-operation, and the abdomen is explored. T-tube drainage treatment has been applied to the patients. The gall fistula was closed after ERCP operation in the other 4 patients. ERCP operation was applied intended for gall fistula to 3 of the patients, who have been operated with four-port method, and the gall fistula was closed. However, upon the development of gall peritonitis in one patient, he/she was re-operated after the operation, and the explorative laparotomy was applied. When the studies in the literature are reviewed, $\mathrm{Ng}$ W: T. has demonstrated that the three-port technique was as safe as the four-port technique. ${ }^{[1]}$ Harsha H.S. ${ }^{[24]}$ and Gurusamy KS et al. ${ }^{[25]}$ demonstrated that the threeport technique increases the risk of biliary tract injury.

Another intra-operative complication is the hemorrhage, seen as a result of cystic artery cut by clip, due to the edematous tissues. This complication was seen only in 1 patient within the three-port group. The hemorrhage was taken under control by placing x-large Hem-o-lok clips (Weck polymer Ligation, Teleflex, Ireland) for that patient. In the other studies in literature, the cystic artery complication has occurred in 3 patients in Sharma et al.'s ${ }^{[26]}$ study, in 4 patients in Duman et al.' ${ }^{[28]}$ study, in 163 patients among 15600 patients in Shea et al.'s ${ }^{[29]}$ study.

This study is made in order to compare whether the threeport method is as practical and safe as standard four-port method in laparoscopic cholecystectomy operations, by reviewing the files and assessing retrospectively.

If we review the results of the study we have made; we think, we have demonstrated that the three-port laparoscopic cholecystectomy is a method, as safe as the stan- dard four-port method, in the hands of experienced general surgery. In addition, as the patient safety is essential in all surgeries; in cases, which the patient's life would be under risk, we recommend entering the $4^{\text {th }}$ port and if necessary, switching to open surgery.

\section{Disclosures}

Peer-review: Externally peer-reviewed.

Conflict of Interest: None declared.

\section{References}

1. Kanat BH, Girgin M. Effects of patients with three port laparoscopic cholecystectomy. J Kartal TR 2012;23:18-20. [CrossRef]

2. Dubois F, Icard P, Berthelot G, Levard H. Coelioscopic cholecystectomy. Preliminary report of 36 cases. Ann Surg 1990;211:60-2. [CrossRef]

3. Litynski GS. Profiles in laparoscopy: Mouret, Dubois, and Perissat: the laparoscopic breakthrough in Europe. JSLS 1999;3:163-7.

4. Trichak S. Three-port vs standard four-port laparoscopic cholecystectomy. Surg Endosc 2003;17:1434-6. [CrossRef]

5. Poon CM, Chan KW, Lee DW, Chan KC, Ko CW, Cheung HY, et al. Two-port versus four port laparoscopic cholecystectomy. Surg Endosc 2003;17:1624-7. [CrossRef]

6. Sarli L, lusco D, Gobbi S, Porrini C, Ferro M, Roncoroni L. Randomized clinical trial of laparoscopic cholecystectomy performed with mini-instruments. Br J Surg 2003;90:1345-8.

7. Tagaya N, Kita J, Takagi K, Imada T, Ishikawa K, Kogure H, et al. Experience with three-port laparoscopic cholecystectomy. J Hepatobiliary Pancreat Surg 1998;5:309-11. [CrossRef]

8. Endo S, Souda S, Nezu R, Yoshikawa Y, Hashimoto J, Mori T, et al. A new method of laparoscopic cholecystectomy using three trocars combined with suture retraction of gallbladder. J Laparoendosc Adv Surg Tech A 2001;11:85-8. [CrossRef]

9. Nathanson LK, Shimi S, Cuschieri A. Laparoscopic cholecystectomy: the Dundee technique. Br J Surg 1991;78:155-9.

10. Navarra G, Pozza E, Occhionorelli S, Carcoforo P, Donini I. One wound laparoscopic cholecysectomy. Br J Surg 1997;84:695.

11. Ng WT. Three trocar laparoscopic cholecystectomy: a cautionary note. Surg Laparosc Endosc 1998;8:159-60. [CrossRef]

12. Olsen DO. Laparoscopic cholecystectomy. Am J Surg 1991;161:339-44. [CrossRef]

13. Hashimoto D, Hirota M, Yagi $Y$, Baba H. Umbilicus Saving Three-Port Laparoscopic Cholecystectomy. WebmedCentral LAPAROSCOPY 2011;2:WMC001882.

14. Otani T, Kaji T, Fukasawa T, Osawa T, Seki F, Yokoyama T, et al. A flower-shaped cannula for three incision laparoscopic cholecystectomy. Surgical Endoscopy 1998;12:179-180.

15. Slim K, Pezet D, Stencl J Jr, Lechner C, Le Roux S, Lointier $P$, et al. Laparoscopic cholecystectomy: an original three-trocar technique. World J Surg 1995; 19:394-7. [CrossRef]

16. Deziel DJ, Millikan KW, Economou SG, Doolas A, Ko ST, Airan 
MC. Complications of cholecystectomy: a national survey of 4292 hospitals and ananalysis of 77,604 cases. Am J Surg 1993;165:9-14. [CrossRef]

17. Bisgaard $\mathrm{T} 1$, Klarskov B, Trap R, Kehlet $H$, Rosenberg J.Pain after microlaparoscopic cholecystectomy. A randomized doubleblind controlled study. Surg Endosc 2000;14:340-4.

18. Leggett PL, Bissell CD, Churchman-Winn R, Ahn C. Three port microlaparoscopic cholecystectomy in 159 patients. Surg Endosc 2001;15:293-6. [CrossRef]

19. Al-Azawi D, Houssein N, Rayis AB, McMahon D, Hehir DJ. Three-port versus four-port laparoscopic cholecystectomy in acute and chronic cholecystitis. BMC Surg 2007;7:8.

20. Lee $\mathrm{JH}$, Seol JW, Jeon CW, et al. A comparison between three-port and four-port technique in the laparoscopic cholecystectomy. Korean Medical Database 2003;6:22-7.

21. Gupta A, Shrivastava UK, Kumar P, Burman D. Minilaparoscopic versus laparoscopic cholecystectomy: A randomized controlled trial. J Tropical Gastroenterology 2005;26:149-51.

22. Kumar M, Agrawal CS, Gupta RK. Three-Port Versus Standard Four-Port Laparoscopic Cholecystectomy: A Randomized Controlled Clinical Trial in a Community-Based Teaching Hospital in Eastern Nepal. JSLS 2007;11:358-62.

23. Lai EC, Yang GP, Tang CN, Yih PC, Chan OC, Li MK. Prospec- tive randomized comparative study of single incision laparoscopic cholecystectomy versus conventional four-port laparoscopic cholecystectomy. Am J Surg 2011;202:254-8.

24. Harsha H S, Gunjiganvi M, Singh C, Moirangthem GS. A study of three-port versus four-port laparoscopic cholecystectomy. J Med Soc 2013;27:208-11. [CrossRef]

25. Gurusamy KS, Samraj K, Ramamoorthy R, Farouk M, Fusai G, Davidson BR. Miniport versus standard ports for laparoscopic cholecystectomy. Cochrane Database Syst Rev 2010;(3):CD006804. [CrossRef]

26. Sharma PK, Mehta KS. Three Port versus Standard Four Port Laparoscopic Cholecystectomy- A Prospective Study. JK Science 2015; 17:38-42.

27. Cerci C, Tarhan O, Barut I, Bulbul M. Three-port versus fourport laparoscopic cholecystectomy. Hepatogastroenterology 2007;54:15-6.

28. Duman K, Sezer KH, Yılmaz F, Akın ML. The clinical outcome of traditional laparoscopic cholecystectomy. Gazıantep Med J 2013;19:35-9. [CrossRef]

29. Shea JA, Healey MJ, Berlin JA, Clarke JR, Malet PF, Staroscik RN, et al. Mortality and complications associated with laparoscopic cholecystectomy. A meta-analysis. Ann Surg 1996;224:609-20. [CrossRef] 